\title{
MicroRNA-433 negatively regulates the expression of thymidylate synthase (TYMS) responsible for 5 -fluorouracil sensitivity in HeLa cells
}

\author{
Keisuke Gotanda ${ }^{\dagger}$, Takeshi Hirota ${ }^{\dagger}$, Nozomi Matsumoto and Ichiro leiri ${ }^{*}$
}

\begin{abstract}
Background: Thymidylate synthase (TYMS) is an important folate-dependent enzyme in DNA synthesis and an important target for cancer chemotherapy. High TYMS expression levels in tumors are generally associated with resistance to 5-fluorouracil (5-FU). The cause of the variability in TYMS expression is still not fully understood, however, only a small proportion of the TYMS expression can be explained by TYMS genetic polymorphisms. The purpose of this study is to identify novel microRNAs (miRNAs) which regulate the expression of TYMS and to determine whether miRNAs binding to the 3'-untranslated region (UTR) of TYMS mRNA affect the proliferation of HeLa cells treated with 5-FU.

Methods: An in silico search was performed to find potential binding sites of miRNAs in TYMS mRNA. The efficacy of predicted miRNAs at the 3'-UTR of TYMS mRNA was evaluated using a dual-luciferase reporter assay. TYMS mRNA and protein expression in HeLa cells was quantified with real-time RT-PCR and Western blotting, respectively. The effects of miR-433 on cell proliferative activity were determined by WST-8 assay.

Results: The overexpression of miR-433 was associated with significantly decreased reporter activity in the plasmid containing the $3^{\prime}-$ UTR of TYMS mRNA $(P<0.01)$. The levels of TYMS mRNA and protein in HeLa cells were significantly decreased by the overexpression of miR-433 $(P<0.05)$. Furthermore, miR-433 increased inhibition of cell proliferation in HeLa cells treated with 5-FU at over $2.0 \mu \mathrm{M}$.

Conclusion: The results indicate that miR-433 post-transcriptionally regulates the expression of TYMS mRNA and protein, and increases sensitivity to 5-FU in HeLa cells. This is the first report showing that a miRNA regulating TYMS expression has a significant impact on sensitivity to 5 -FU treatment.
\end{abstract}

Keywords: MicroRNAs, miR-433, Thymidylate synthase, Fluorouracil

\section{Background}

Thymidylate synthase (TYMS) is an intracellular enzyme critical for de novo synthesis of thymidine monophosphate (dTMP), a precursor of the DNA metabolite thymidine triphosphate. Inhibition of TYMS suppresses cellular growth and leads to cell death. Due to this critical function, TYMS has been a major target of anti-cancer drugs for the past

\footnotetext{
* Correspondence: ieiri-ttr@umin.ac.jp

${ }^{\dagger}$ Equal contributors

Department of Clinical Pharmacokinetics, Graduate School of Pharmaceutical Sciences, Kyushu University, 3-1-1 Maidashi Higashi-ku, Fukuoka 812-8582,
} Japan

\section{Biomed Central}

(c) 2013 Gotanda et al.; licensee BioMed Central Ltd. This is an Open Access article distributed under the terms of the Creative Commons Attribution License (http://creativecommons.org/licenses/by/2.0), which permits unrestricted use, distribution, and reproduction in any medium, provided the original work is properly cited.
50 years [1]. Five-fluorouracil (5-FU), one of several TYMS inhibitors, is widely used to induce temporary tumor regression and improve survival, especially for gastrointestinal cancers [2]. The level of TYMS expression is known to be related to the response of tumor cells to 5FU. Overexpression of TYMS in human colon cancer cells induced resistance to fluoropyrimidine [3]. In addition, higher TYMS levels in tumor tissues in cancer patients were associated with resistance to 5-FU-based chemotherapy [4-7].

There is considerable interindividual variability in the clinical response to 5-FU [8]. The 5-FU dose in cancer 
patients has yet to be well standardized, due to high variability in plasma 5-FU levels, up to 100-fold [9], leading to undesired side effects. This variability may be the major contributor to toxicity and subsequent treatment failure $[10,11]$. Dose management of 5-FU could therefore prove essential to reducing 5-FU toxicity in patients. Interindividual differences in TYMS expression may be responsible for the different clinical responses to 5-FU. Indeed, a large difference in TYMS mRNA expression was observed between colorectal tumor and normal tissues [12]. Three functionally important polymorphisms were identified in the TYMS gene: (i) rs34743033: a variable number of 28-bp tandem repeat polymorphisms in the promoter region of the $5^{\prime}$-untranslated enhancer region (UTR) [13]; (ii) rs16430: a 6-bp deletion in the $3^{\prime}$-UTR [14]; and (iii) rs2853542: a G/C polymorphism in the $5^{\prime}$-UTR enhancer region [15]. These polymorphisms showed a significant association with poor outcome in 5-FU-treated patients [16-18]. However, some reports have indicated that TYMS polymorphisms did not affect the response to 5-FU therapy $[12,19]$.

MicroRNAs (miRNAs) constitute a class of endogenous, small (19-25 nucleotides), non-coding single-stranded RNAs, and negatively regulate the translation of multiple mRNAs by binding to their $3^{\prime}$-UTRs and inhibiting mRNA translation or breaking down mRNA [20]. It has been reported that miRNAs play an important role as either oncogenes or tumor suppressors, therefore, miRNAs have been increasingly recognized as useful biomarkers, as well as therapeutic tools [21,22]. Moreover, recent evidence suggests that miRNA expression influences chemosensitivity in human cancer cells [23-26].

TYMS expression is reported to be regulated by miR192 and miR-215 in colorectal cancer cell lines [27]. However, down regulation of TYMS expression by these miRNAs did not sensitize cells to 5-FU in colorectal cancers. Although high TYMS levels are associated with resistance to 5-FU-based chemotherapy [4-7], no miRNAs which repress TYMS expression leading to an increase in sensitivity to 5-FU, have been identified. Interestingly, the 6-bp deletion (rs16430) in the TYMS 3'-UTR is reported to decrease mRNA stability in vitro and gene expression in vivo [28]. These results suggest that certain miRNAs, which target sites proximal to the 6-bp deletion resulting in lower TYMS expression, exist.

In the current study, we identified a novel miRNA regulating the expression of TYMS and evaluated its effect on the proliferation of a human cervical cancer cell line exposed to 5-FU.

\section{Methods}

\section{Cell culture}

The human cervical cancer HeLa cell line was obtained from RIKEN Cell Bank. HeLa cells were cultured in
Dulbecco's modified Eagle's medium (DMEM) (SigmaAldrich, St. Louis, MO, USA) supplemented with $10 \%$ fetal bovine serum (FBS) (Nichirei Biosciences Inc., Tokyo, Japan) and incubated at $37^{\circ} \mathrm{C}$ in $5 \%$ carbon dioxide.

\section{Dual luciferase reporter assays}

The full-length 3'-UTR of TYMS gene with and without the 6-bp deletion was amplified from human genomic DNA using forward and reverse primers (Forward 5' - TCATCTAGAACCCAGACCTT -3', Reverse 5' - CCAATCTAGAATACAGCACA -3'). XbaI (TaKaRa Inc., Otsu, Japan) restriction sites were created in the primers for cloning. The products were cloned into the pGL3 Promoter vector (Promega, Madison, WI, USA) and named the pGL3 + reference allele or pGL3 + 6 bp deletion allele. Control luciferase constructs were made by ligating oligonucleotides containing a perfect complementary sequence to miR-433 into the XbaI site of the pGL3 Promoter vector (pGL3 + miR-433). HeLa cells were plated in a 24-well plate at a density of $6.0 \times$ $10^{4}$ cells/well and maintained in DMEM with $10 \%$ FBS at $37^{\circ} \mathrm{C}$ in $5 \%$ carbon dioxide. After 24 hours, $380 \mathrm{ng}$ of reporter plasmid, 20 ng of pRL-TK (Promega), and negative control precursor miRNA (pre-miR-negative control) (Applied Biosystems Life Technologies, Carlsbad, CA, USA) or pre-miR-433 miRNA precursor (premiR-433) (Applied Biosystems) were transfected by using Lipofectamine 2000 (Invitrogen Life Technologies, Carlsbad, CA, USA). Reporter assays were performed at 48 hours post-transfection using the Dual luciferase assay system (Promega), and normalized for transfection efficiency by co-transfected Renilla-luciferase.

Transfections of miRNA and small interfering RNA (siRNA) For Western blotting and quantification of mRNA expression, $0.75,1.5$, and $3.0 \mathrm{nM}$ of pre-miR-negative control, pre-miR-433, TYMS siRNA (On-Target plus SMART pool L-004717-00-0005, Dharmacon, Denver, CO, USA) and $1.0 \mu \mathrm{L} /$ well Lipofectamine 2000 were mixed with OptiMEM I medium (Invitrogen), then introduced into HeLa cells $\left(1.0 \times 10^{5}\right.$ cells/well $)$ in a 24 -well plate.

\section{RNA isolation and quantitative reverse transcription-PCR analysis of TYMS mRNA}

Total RNA from HeLa cells was extracted using the miRVana PARIS kit (Ambion Life Technologies, Carlsbad, CA, USA) according to the manufacturer's instructions at 48 hours after transfection. The RNA samples were then reverse-transcribed into first strand cDNA with $200 \mathrm{ng}$ of total RNA, $2.0 \mu \mathrm{l}$ of $5 \times$ first strand buffer, $2.0 \mu \mathrm{l}$ of $0.1 \mathrm{mM}$ DTT, $0.5 \mu \mathrm{l}$ of $500 \mu \mathrm{g} / \mathrm{ml}$ random primer (Promega), $2.0 \mu \mathrm{l}$ of $10 \mathrm{mM} \mathrm{dNTP}$ mixture and 100 units of SuperScript II RNase H-reverse transcriptase 
(Invitrogen). The reaction mixture was incubated at $42^{\circ} \mathrm{C}$ for 60 minutes. The mRNA level was measured with a real-time PCR system (Applied Biosystems). The following primers were used: for the TYMS mRNA, $5^{\prime}$ TCTGGAAGGGTGTTTTGGAG-3' (forward) and 5' CCTCCACTGGAAGCCATAAA-3' (reverse), and for the $\beta$-actin $(A C T B)$ mRNA, 5'-ATGTGGCCGAGGAC TTTGATT-3' (forward) and 5' -AGTGGGGTGGCTTT TAGGATG-3' (reverse).

\section{Western blotting}

HeLa cells were harvested and homogenized with CelLytic M cell Lysis Reagent (Sigma-Aldrich) and Protease Inhibitor Cocktail (Sigma-Aldrich) at 48 hours after transfection. The lysate samples were separated on $12 \%$ SDS-polyacrylamide gels and transferred to polyvinylidene membranes. The membranes were hybridized with a mouse monoclonal antibody against human TYMS (Abcam Inc., Cambridge, MA, USA) and $\beta$-actin (Sigma-Aldrich). The immunocomplexes were hybridized with anti-mouse IgG horseradish peroxidaselinked whole antibody (GE Healthcare, Little Chalfont, Buckinghamshire, UK). Membranes were washed two times in PBS-Tween, and specific bands were visualized using the ECL system (GE Healthcare) according to the manufacturer's instructions.

\section{5-FU chemosensitivity}

HeLa cells were plated onto a 96-well plate and incubated for 24 hours $\left(4.0 \times 10^{3}\right.$ cells/well). They were then transfected with Pre-miR-negative control (3.0 nM), pre-miR-433 (3.0 nM) or TYMS siRNA (3.0 nM) and treated in 5-FU (Wako, Osaka, Japan) at a final concentration of $0.1,0.5,1.0,2.0,3.0,4.0$, or $5.0 \mu \mathrm{M}$. Cell proliferation was assessed at 120 hours post-transfection using Cell Counting Kit-8 (Dojindo Laboratories Co., Ltd., Kumamoto, Japan) following the manufacturer's directions.

\section{Statistical analysis}

Statistical analyses were performed with the statistical software program $\mathrm{R}$ version 2.13.1 (R Development Core Team, 2011). Means for two groups were compared with an unpaired Student's $t$-test (two-tailed). Comparisons of means for multiple groups against the pre-miR-negative control transfected cells were analyzed with Dunnett's multiple comparison tests. A $5 \%$ level of probability was considered to be significant.

\section{Results}

Prediction of miRNAs targeting the 3'-UTR of TYMS mRNA To identify miRNAs targeting the 3'-UTR of TYMS mRNA, we used the programs TargetScan (http://www. targetscan.org) and MiRanda (http://www.microrna.org).
MiR-433 was selected as a candidate miRNA binding to the 3'-UTR of TYMS mRNA based on matching sites (Figure 1). The 6-bp deletion (rs16430) was located 22 bp downstream from the predicted miR-433-binding site.

\section{Repressive regulation in the 3'-UTR of TYMS mRNA by miR-433}

The sequence complementary to the miR-433-binding site and two full-length human TYMS 3'-UTR sequences (the wild type or 6-bp deletion) were inserted downstream of the luciferase reporter gene. We measured luciferase reporter activity as the effects of repressive post-transcriptional regulation by miR-433. The luciferase vector with the 6-bp deletion allele showed significantly lower activity than the wild-type allele in the negative control miRNA-transfected cells $(P<0.05$, Figure 2). On the other hand, over expression of miR433 significantly decreased the reporter activity in the cells with the 3 '-UTR-inserted vectors compared to the negative control.

\section{Effects of overexpression of miR-433 on TYMS mRNA levels in HeLa cells}

To verify the effect of the overexpression of miR-433 on TYMS mRNA levels, HeLa cells were temporarily transfected with the pre-miR-negative control, pre-miR-433 or TYMS siRNA (positive control) and TYMS mRNA levels were quantitated by real-time RT-PCR analysis using $A C T B$ for normalization. The overexpression of $\mathrm{miR}-433$ significantly decreased TYMS mRNA levels in a precursor concentration-dependent manner; reduced by approximately $50 \%$ at $3.0 \mathrm{nM}$ of pre-miR-433 as compared with the negative control (Figure 3 ).

\section{Effects of overexpression of miR-433 on TYMS protein levels in HeLa cells}

At all precursor concentrations, siRNA resulted in TYMS protein deficiency, and miR-433 significantly reduced TYMS protein expression compared to the negative control (Figure 4A, B). Transient transfection of 3.0 $\mathrm{nM}$ pre-miR-433 resulted in a $40 \%$ reduction in TYMS protein expression (Figure 4B).

\section{Effects of overexpression of miR-433 on sensitivity to 5-FU in HeLa cells}

To evaluate the effect of miR-433 on the sensitivity to 5FU treatment, we performed WST-8 assays on HeLa cells transiently transfected with the pre-miR-negative control, pre-miR-433 or TYMS siRNA. First, we analyzed the effects of overexpression of miR-433 and knock-down of TYMS on cell proliferation without 5-FU treatment; there was no change in proliferation among the transfected cells (Figure 5A). TYMS siRNA significantly decreased proliferation in cells treated with over 


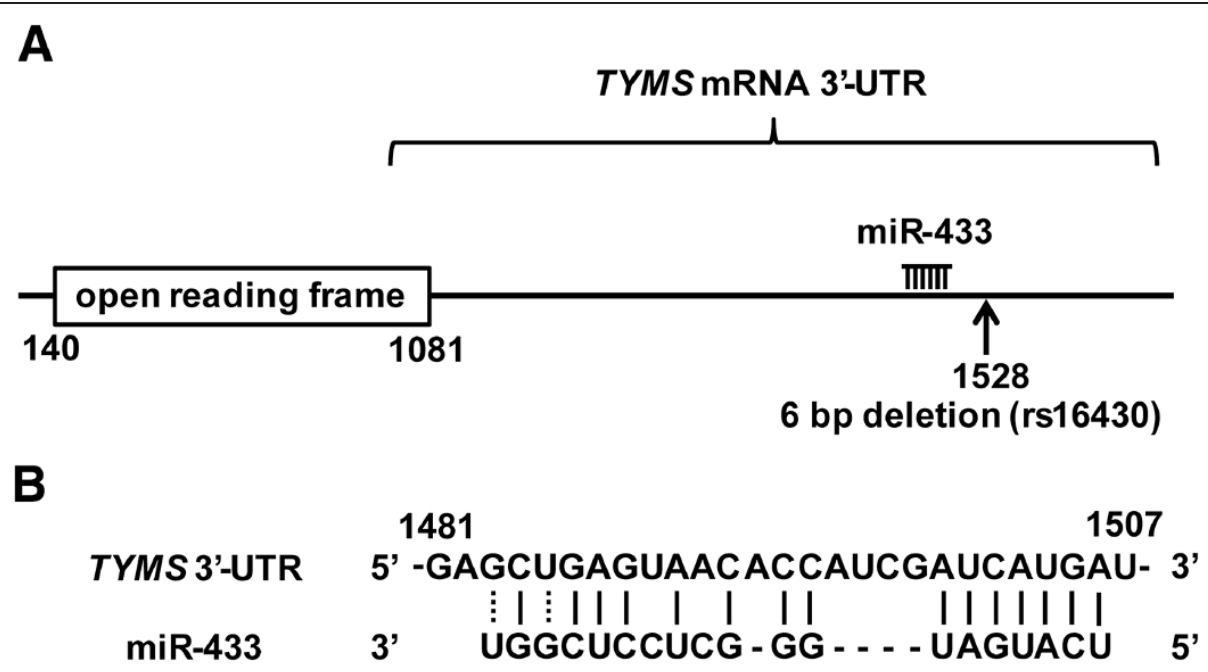

Figure 1 Prediction of miRNA-binding sites in the 3'-UTR of TYMS mRNA. (A) The locations of the 6-bp deletion (indicated as arrow) and predicted miR-433-binding site in the 3'-UTR of TYMS mRNA. (B) Homology between the 3'-UTR of TYMS mRNA and the predicted target sequence of miR-433. Numbers indicate mRNA positions.

$0.5 \mu \mathrm{M}$ of 5 -FU compared to the pre-miR-negative control (Figure 5B). In cells overexpressing miR-433, proliferation was not affected at 5-FU concentrations ranging from 0.1 to $1.0 \mu \mathrm{M}$; however, the decrease in cell proliferation was remarkable over $2.0 \mu \mathrm{M}$, and comparable with that by TYMS siRNA over $3.0 \mu \mathrm{M}$. These results indicate that overexpression of miR-433 sensitizes HeLa cells to 5-FU treatment.

\section{Discussion and conclusion}

In the present study, we tried to identify a novel miRNA which regulates the expression of TYMS, and evaluate its effects on 5-FU treatment using HeLa cells. After the screening of miRNAs targeting the 3'-UTR of TYMS
mRNA, miR-433 was predicted to be located in the 3 'UTR proximal to the 6-bp deletion (rs16430). Interestingly, the 6-bp deletion has been associated with decreased mRNA stability and lower gene expression. To demonstrate that miR-433 directly targets the 3 '-UTR with or without 6-bp deletion allele, we analyzed the luciferase activity using the vector containing the two alleles. The luciferase vector with the 6-bp deletion allele showed significantly less activity than that with the wild-type vector, suggesting that the 6-bp deletion in the 3'-UTR was involved in the post-transcriptional regulation of TYMS expression. Mandola et al. reported that the 6-bp deletion influenced TYMS mRNA stability [28]. As shown in Figure 2, overexpression of miR-433 decreased the

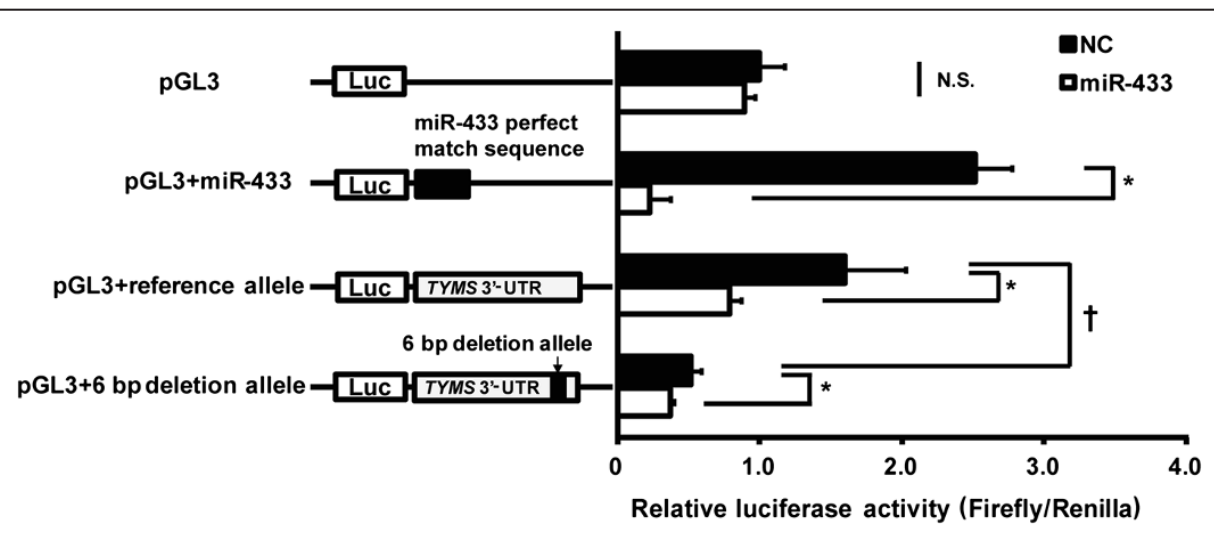

Figure 2 Repressive regulation of luciferase activity including the human 3'-UTR of TYMS by miR-433. Reporter constructs containing the full-length 3'-UTR of TYMS were transiently introduced with 3.0 nM of pre-miR-negative control (NC) or pre-miR-433 (miR-433) into HeLa cells. Luciferase activity was normalized to Renilla luciferase activity. Relative luciferase activity is expressed as a ratio of the Renilla luciferase activity of each precursor. Each column represents the mean \pm S.E. for three independent experiments. ${ }^{*}, P<0.01$, compared with the precursor for the negative control determined by an unpaired two-sample $t$-test.,$+ P<0.05$, compared with $\mathrm{pGL} 3+6$-bp deletion for the negative control determined by an unpaired two-sample t-test. N.S.: not significant. 


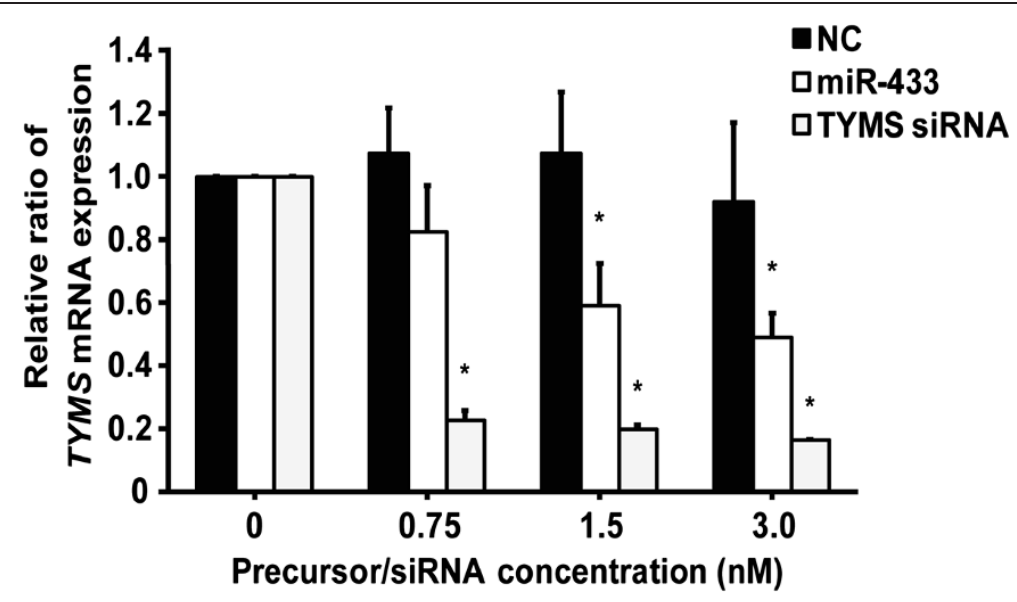

Figure 3 Effects of overexpression of miR-433 on TYMS mRNA levels in HeLa cells. Hela cells were transfected with pre-miR-negative control (NC), pre-miR-433 (miR-433) or TYMS siRNA $(0.75,1.5$ and $3.0 \mathrm{nM}$ ). The relative TYMS mRNA level was normalized with $\beta$-actin. Results represent the mean \pm S.D. for four independent experiments. Relative TYMS mRNA levels were expressed as ratios of the relative TYMS mRNA of the precursor for the negative control. ${ }^{*}, P<0.05$, compared with the negative control determined by Dunnett's multiple comparison tests.

luciferase activity, suggesting that miR-433 directly repressed TYMS expression, but it was independently observed for the 6-bp deletion allele. Transfection with the miR-433 precursor significantly decreased TYMS mRNA and protein levels in a precursor miRNA concentrationdependent manner (Figures 3 and 4). It was suggested that miR-433 suppresses the expression of the endogenous TYMS protein by controlling the stability of TYMS
mRNA transcripts. Taking these observations into consideration, miR-433 acts as a repressive regulator, but is not responsible for the decreased mRNA stability due to the 6-bp deletion.

TYMS is considered the primary target of 5-FU $[29,30]$. It has been suggested that high TYMS expression is correlated with low sensitivity to 5 -FU $[31,32]$. In addition to TYMS genetic polymorphisms, the contribution of

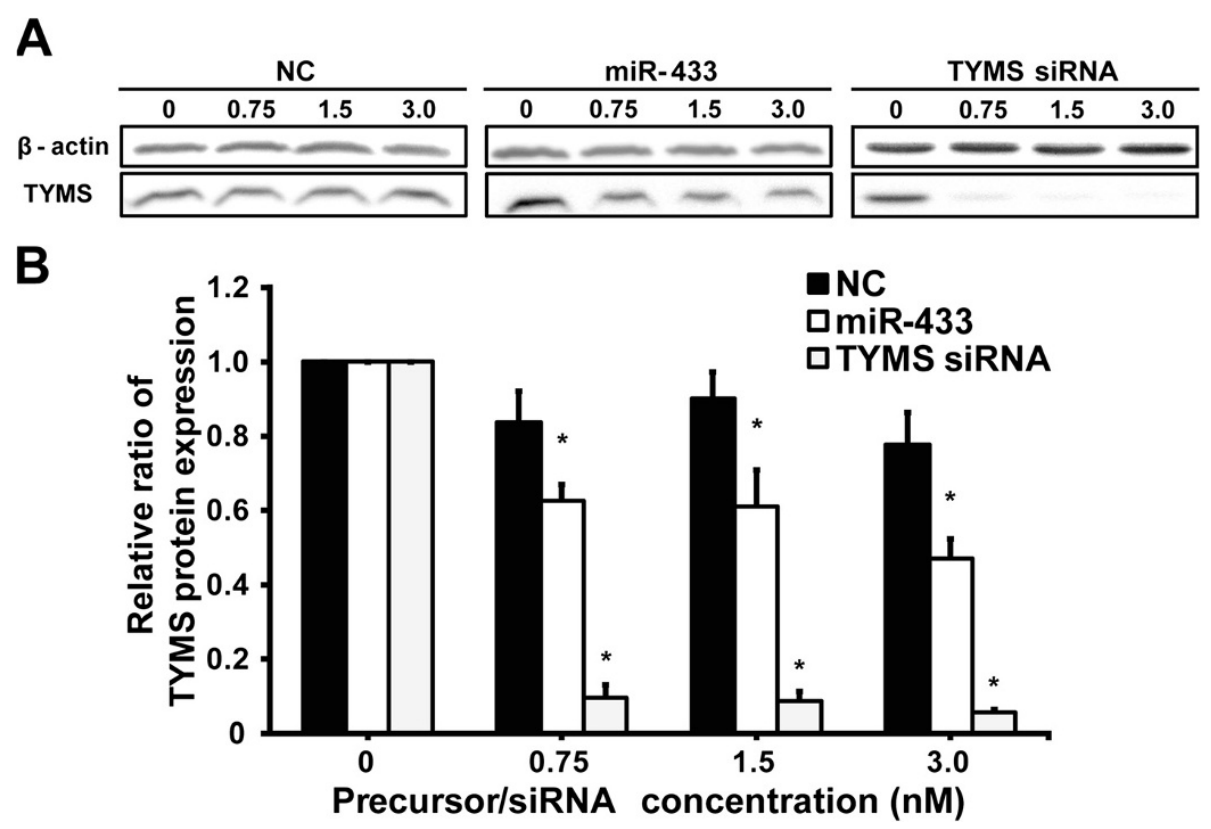

Figure 4 Effects of overexpression of miR-433 on TYMS protein levels in HeLa cells. (A) Hela cells were transfected with pre-miR-negative control (NC), pre-miR-433 (miR-433) or TYMS siRNA (0.75, 1.5 and $3.0 \mathrm{nM}$ ). TYMS protein levels were determined by Western blotting. (B) Relative TYMS protein levels represent the mean \pm S.D. for three independent experiments. The TYMS level was normalized with $\beta$-actin. Relative TYMS protein levels were expressed as the ratio of the normalized TYMS level to the pre-miR-negative control. ${ }^{*}, P<0.05$, compared with the negative control determined by Dunnett's multiple comparison tests. 


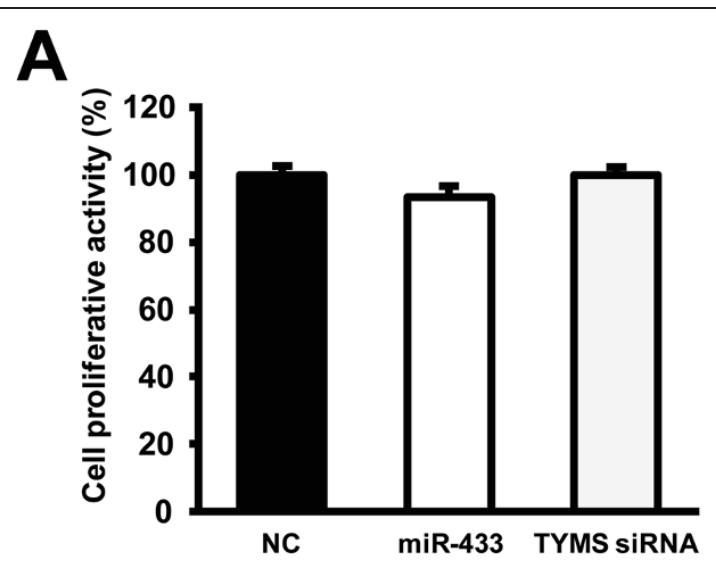

B

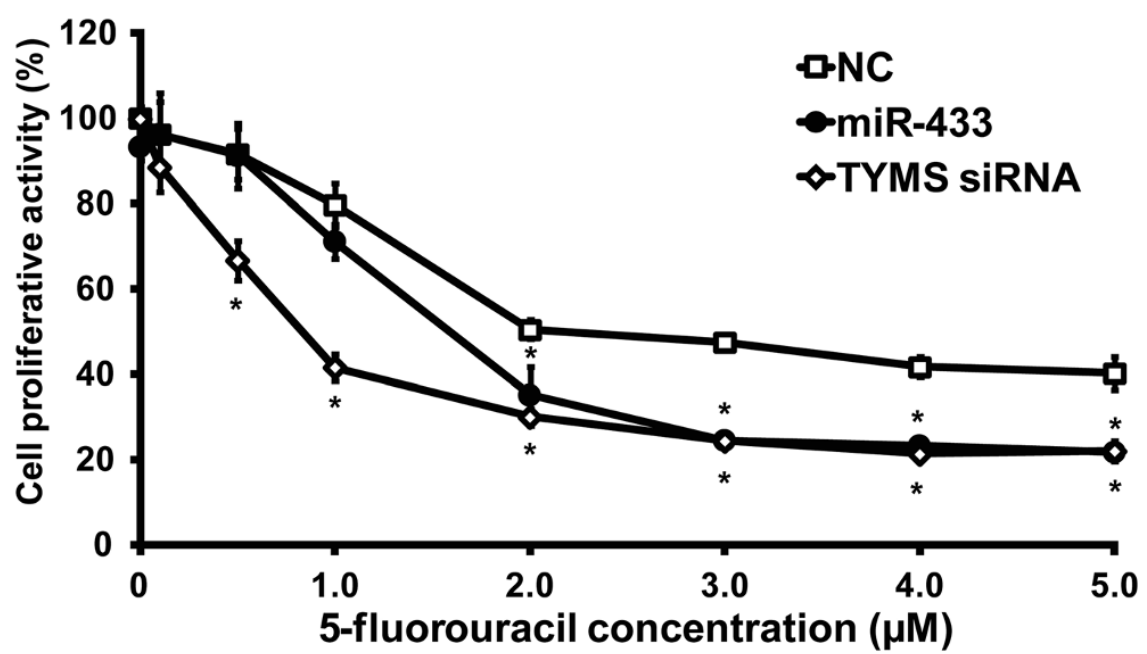

Figure 5 Effects of miR-433 on the sensitivity to 5-FU in HeLa cells. (A) HeLa cells were transfected with 3.0 nM of pre-miR-negative control (NC), pre-miR-433 (miR-433) or TYMS siRNA. Cell proliferative activities were determined by WST-8 assay. Each column represents the mean \pm S.E. for three independent experiments. (B) 5-FU chemosensitivity in HeLa cells was measured by WST-8 assay. Each point represents the mean \pm S.D. for three independent experiments. ${ }^{*} P<0.01$, compared with the negative control determined by Dunnett's multiple comparison tests.

miRNAs to sensitivity to 5-FU treatment has recently been studied. MiR-192/215 decreased TYMS mRNA and protein levels, but significantly reduced sensitivity to 5-FU by targeting cell cycle progression [27]. To date, no miRNA which represses TYMS expression leading to an increase in sensitivity to 5-FU has been identified. In addition to TYMS, miR-433 also targets tumor-associated protein growth factor receptor-bound protein 2 (GRB2) involved in the molecular pathogenesis of gastric cancer [33]. MiR433 expression was reported to be down-regulated in gastric carcinoma [33]. Furthermore, gastric cancer patients with low expression of miR-433 showed lower survival rates than patients with high expression [34]. Previous reports indicated that miR-433 acts as an anti-oncogenic miRNA (anti-oncomir). However, as shown in Figure 5A, overexpression of miR-433 did not affect cell proliferation in HeLa cells without 5-FU treatment. Our experimental concentration for transfection (at $3.0 \mathrm{nM}$ ) was approximately 7-fold lower than that of the previous report (at 25-50 nM) [33]. It is possible that miR-433 does not act as an anti-oncomir at lower concentrations.

Conversely, we showed that miR-433 decreased the proliferation of HeLa cells treated with over $2.0 \mu \mathrm{M}$ of 5-FU. A concentration of $2.0 \mu \mathrm{M}$, approximately $260 \mu \mathrm{g} /$ $\mathrm{L}$, is close to the clinical target range of 5-FU; indeed, $450-550 \mu \mathrm{g} / \mathrm{L}$ is recommended for FOLFOX6 in metastatic colorectal cancer patients with grade $0-1$ toxicity [9]. Hence, miR-433 may improve the efficiency of 5-FU chemotherapy in keeping with Luo's report [33] that overexpression of miR-433 acts as an anti-oncomir.

This study showed that miR-433 had a significant impact on sensitivity to 5 -FU by regulating TYMS expression in vitro. Overexpression of TYMS has been linked to drug resistance [7]. Since miR-433 regulates TYMS 
expression, it is expected to influence the effect of some TYMS-related drugs (e.g., methotrexate). If this is true, miR-433 may have potential as an adjuvant therapeutic to overcome drug resistance.

TYMS, thymidylate synthase; dTMP, thymidine monophosphate; 5-FU, 5-fluorouracil; UTR, untranslated enhancer region; miRNAs, microRNAs.

\section{Competing interests}

The authors declare that they have no competing interests.

\section{Authors' contributions}

KG: data acquisition, quality control of data, statistical analysis and manuscript preparation; TH: study concepts, design of the study, data analysis, interpretation of the study and manuscript preparation; NM: data acquisition; II: study concepts and manuscript review. All authors read and approved the final manuscript.

\section{Acknowledgements}

We appreciate the technical support from the Research Support Center, Graduate School of Medical Sciences, Kyushu University.

Received: 9 April 2013 Accepted: 1 August 2013

Published: 2 August 2013

\section{References}

1. Di Cresce C, Figueredo R, Ferguson PJ, Vincent MD, Koropatnick J: Combining small interfering RNAs targeting thymidylate synthase and thymidine kinase 1 or 2 sensitizes human tumor cells to 5-fluorodeoxyuridine and pemetrexed. J Pharmacol Exp Ther 2011, 338:952-963.

2. Longley DB, Harkin DP, Johnston PG: 5-fluorouracil: mechanisms of action and clinical strategies. Nat Rev Cancer 2003, 3:330-338

3. Copur S, Aiba K, Drake JC, Allegra CJ, Chu E: Thymidylate synthase gene amplification in human colon cancer cell lines resistant to 5 -fluorouracil. Biochem Pharmacol 1995, 49:1419-1426.

4. Kaira K, Serizawa M, Koh Y, Miura S, Kaira R, Abe M, Nakagawa K, Ohde Y, Okumura T, Murakami H, Tsuya A, Nakamura Y, Naito T, Takahashi T, Kondo H, Nakajima T, Endo M, Yamamoto N: Expression of thymidylatesynthase, orotate phosphoribosyltransferase and dihydropyrimidine dehydrogenase in thymic epithelial tumors. Lung Cancer 2011, 74:419-425.

5. Nakano J, Huang C, Liu D, Masuya D, Nakashima T, Yokomise H, Ueno M, Wada H, Fukushima M: Evaluations of biomarkers associated with 5-FU sensitivity for non-small-cell lung cancer patients postoperatively treated with UFT. Br J Cancer 2006, 95:607-615.

6. Yeh KH, Shun CT, Chen CL, Lin JT, Lee WJ, Lee PH, Chen YC, Cheng AL: High expression of thymidylate synthase is associated with the drug resistance of gastric carcinoma to high dose 5-fluorouracil-based systemic chemotherapy. Cancer 1998, 82:1626-1631.

7. Johnston PG, Lenz HJ, Leichman CG, Danenberg KD, Allegra CJ, Danenberg $P V$, Leichman $L$ : Thymidylate synthase gene and protein expression correlate and are associated with response to 5-fluorouracil in human colorectal and gastric tumors. Cancer Res 1995, 55:1407-1412.

8. Gamelin EC, Danquechin-Dorval EM, Dumesnil YF, Maillart PJ, Goudier MJ, Burtin PC, Delva RG, Lortholary AH, Gesta PH, Larra FG: Relationship between 5 -fluorouracil (5-FU) dose intensity and therapeutic response in patients with advanced colorectal cancer receiving infusional therapy containing 5-FU. Cancer 1996, 77:441-451.

9. Saif MW, Choma A, Salamone SJ, Chu E: Pharmacokinetically guided dose adjustment of 5-fluorouracil: a rational approach to improving therapeutic outcomes. J Natl Cancer Inst 2009, 101:1543-1552.

10. Kline CL, Sheikh HS, Scicchitano A, Gingrich R, Beachler C, Finnberg NK, Liao J, Sivik J, El-Deiry WS: Preliminary observations indicate variable patterns of plasma 5-fluorouracil (5-FU) levels during dose optimization of infusional 5-FU in colorectal cancer patients. Cancer Biol Ther 2011, 12:557-568

11. Gamelin E, Delva R, Jacob J, Merrouche Y, Raoul JL, Pezet D, Dorval E, Piot G, Morel A, Boisdron-Celle M: Individual fluorouracil dose adjustment based on pharmacokinetic follow-up compared with conventional dosage: results of a multicenter randomized trial of patients with metastatic colorectal cancer. J Clin Oncol 2008, 26:2099-2105.

12. Vignoli M, Nobili S, Napoli C, Putignano AL, Morganti M, Papi L, Valanzano R, Cianchi F, Tonelli F, Mazzei T, Mini E, Genuardi M: Thymidylate synthase expression and genotype have no major impact on the clinical outcome of colorectal cancer patients treated with 5-fluorouracil. Pharmacol Res 2011, 64:242-248.

13. Horie N, Aiba H, Oguro K, Hojo H, Takeishi K: Functional analysis and DNA polymorphism of the tandemly repeated sequences in the 5 '-terminal regulatory region of the human gene for thymidylate synthase. Cell Struct Funct 1995, 20:191-197.

14. Ulrich CM, Bigler J, Velicer CM, Greene EA, Farin FM, Potter JD: Searching expressed sequence tag databases: discovery and confirmation of a common polymorphism in the thymidylate synthase gene. Cancer Epidemiol Biomarkers Prev 2000, 9:1381-1385.

15. Mandola MV, Stoehlmacher J, Muller-Weeks S, Cesarone G, Yu MC, Lenz HJ, Ladner RD: A novel single nucleotide polymorphism within the $5^{\prime}$ tandem repeat polymorphism of the thymidylate synthase gene abolishes USF-1 binding and alters transcriptional activity. Cancer Res 2003, 63:2898-2904

16. Afzal S, Gusella M, Jensen SA, Vainer B, Vogel U, Andersen JT, Brødbæk K, Petersen M, Jimenez-Solem E, Adleff V, Budai B, Hitre E, Láng I, Orosz E, Bertolaso L, Barile C, Padrini R, Kralovánszky J, Pasini F, Poulsen HE: The association of polymorphisms in 5 -fluorouracil metabolism genes with outcome in adjuvant treatment of colorectal cancer [abstract]. Pharmacogenomics 2011, 12:1257-1267.

17. Cho HJ, Park YS, Kang WK, Kim JW, Lee SY: Thymidylate synthase (TYMS) and dihydropyrimidine dehydrogenase (DPYD) polymorphisms in the Korean population for prediction of 5-fluorouracil-associated toxicity [abstract]. Ther Drug Monit 2007, 29:190-196.

18. Jennings BA, Kwok CS, Willis G, Matthews V, Wawruch P, Loke YK: Functional polymorphisms of folate metabolism and response to chemotherapy for colorectal cancer, a systematic review and metaanalysis [abstract]. Pharmacogenet Genomics 2012, 22:290-304.

19. Fariña-Sarasqueta A, Gosens MJ, Moerland E, Van Lijnschoten I, Lemmens $V E$, Slooter GD, Rutten HJ, van den Brule AJ: TS gene polymorphisms are not good markers of response to 5-FU therapy in stage III colon cancer patients. Cell Oncol (Dordr) 2011, 34:327-335.

20. Lee RC, Feinbaum RL, Ambros V: The C. elegans heterochronic gene lin- 4 encodes small RNAs with antisense complementarity to lin-14. Cell 1993, 75:843-854.

21. Spizzo R, Nicoloso MS, Croce CM, Calin GA: SnapShot: MicroRNAs in Cancer. Cell 2009, 137:586-586.e1

22. Nicoloso MS, Spizzo R, Shimizu M, Rossi S, Calin GA: MicroRNAs-the micro steering wheel of tumour metastases. Nat Rev Cancer 2009, 9:293-302.

23. Liu H, D'Andrade P, Fulmer-Smentek S, Lorenzi P, Kohn KW, Weinstein JN, Pommier Y, Reinhold WC: mRNA and microRNA expression profiles of the NCl-60 integrated with drug activities. Mol Cancer Ther 2010, 9:1080-1091.

24. Zhou M, Liu Z, Zhao Y, Ding Y, Liu H, Xi Y, Xiong W, Li G, Lu J, Fodstad O, Riker Al, Tan M: MicroRNA-125b confers the resistance of breast cancer cells to paclitaxel through suppression of pro-apoptotic $\mathrm{Bcl}-2$ antagonist killer 1 (Bak1) expression. J Biol Chem 2010, 285:21496-21507.

25. Bai H, Xu R, Cao Z, Wei D, Wang C: Involvement of miR-21 in resistance to daunorubicin by regulating PTEN expression in the leukaemia K562 cell line. FEBS Lett 2011, 585:402-408.

26. Tomimaru Y, Eguchi H, Nagano H, Wada H, Tomokuni A, Kobayashi S, Marubashi S, Takeda Y, Tanemura M, Umeshita K, Doki Y, Mori M: MicroRNA-21 induces resistance to the anti-tumour effect of interferon- $a$ /5-fluorouracil in hepatocellular carcinoma cells. Br J Cancer 2010, 103:1617-1626.

27. Boni V, Bitarte N, Cristobal I, Zarate R, Rodriquez J, Maiello E, Garcia-Foncillas J, Bandres E: miR-192/miR-215 influence 5-fluorouracil resistance through cell cycle-mediated mechanisms complementary to its post-transcriptional thymidilate synthase regulation. Mol Cancer Ther 2010, 9:2265-2275.

28. Mandola MV, Stoehlmacher J, Zhang W, Groshen S, Yu MC, labal S, Lenz HJ, Ladner RD: A 6 bp polymorphism in the thymidylate synthase gene causes message instability and is associated with decreased intratumoral TS mRNA levels. Pharmacogenetics 2004, 14:319-327.

29. Danenberg PV: Thymidylate synthetase - a target enzyme in cancer chemotherapy. Biochim Biophys Acta 1977, 473:73-92. 
30. Radparvar S, Houghton PJ, Houghton JA: Characteristics of thymidylate synthase purified from a human colon adenocarcinoma. Arch Biochem Biophys 1988, 260:342-350.

31. Leichman CG, Lenz HJ, Leichman L, Danenberg K, Baranda J, Groshen S, Boswell W, Metzger R, Tan M, Danenberg PV: Quantitation of intratumoral thymidylate synthase expression predicts for disseminated colorectal cancer response and resistance to protracted-infusion fluorouracil and weekly leucovorin. J Clin Oncol 1997, 15:3223-3229.

32. Lenz HJ, Leichman CG, Danenberg KD, Danenberg PV, Groshen S, Cohen H, Laine L, Crookes P, Silberman H, Baranda J, Garcia Y, Li J, Leichman L:

Thymidylate synthase mRNA level in adenocarcinoma of the stomach: a predictor for primary tumor response and overall survival. I Clin Oncol 1996, 14:176-182.

33. Luo H, Zhang H, Zhang Z, Zhang X, Ning B, Guo J, Nie N, Liu B, Wu X: Down-regulated miR-9 and miR-433 in human gastric carcinoma. J Exp Clin Cancer Res 2009, 28:82.

34. Ueda T, Volinia S, Okumura H, Shimizu M, Taccioli C, Rossi S, Alder H, Liu CG Oue N, Yasui W, Yoshida K, Sasaki H, Nomura S, Seto Y, Kaminishi M, Calin GA, Croce CM: Relation between microRNA expression and progression and prognosis of gastric cancer: a microRNA expression analysis. Lancet Oncol 2010, 11:136-146.

doi:10.1186/1471-2407-13-369

Cite this article as: Gotanda et al:: MicroRNA-433 negatively regulates the expression of thymidylate synthase (TYMS) responsible for 5fluorouracil sensitivity in HeLa cells. BMC Cancer 2013 13:369.

\section{Submit your next manuscript to BioMed Central and take full advantage of:}

- Convenient online submission

- Thorough peer review

- No space constraints or color figure charges

- Immediate publication on acceptance

- Inclusion in PubMed, CAS, Scopus and Google Scholar

- Research which is freely available for redistribution 